\title{
PENGARUH REBUSAN DAUN SIRIH TERHADAP PENURUNAN JUMLAH CANDIDA ALBICANS PADA PLAT RESIN AKRILIK HEAT CURED
}

\author{
Fransiska Nuning Kusmawati*, Tiara Fahriliyandi Putri** \\ *Departemen Prostodonsia, Fakultas Kedokteran Gigi, Universitas Prof. Dr. Moestopo (Beragama), Jakarta \\ **Mahasiswa Profesi, Fakultas Kedokteran Gigi, Universitas Prof. Dr. Moestopo (Beragama), Jakarta, Indonesia \\ Korespondensi: Fransiska Nuning, nuningphynx@gmail.com
}

\begin{abstract}
ABSTRAK
Latar belakang: gigi tiruan yang terbuat dari resin akrilik sering menjadi tempat pertumbuhan Candida albicans, bila tidak dibersihkan dengan baik akan menyebabkan candidiasis. Gigi tiruan dapat dibersihkan untuk menghilangkan pertumbuhan Candida albicans, salah satunya adalah menggunakan tanaman daun sirih. Daun sirih (Piper betle L.) diketahui berkhasiat sebagai antijamur dan desinfektan. Tujuan: untuk mengetahui pertumbuhan Candida albicans pada plat resin aklik yang direndam dalam rebusan daun sirih 50\% dan 70\%. Metode: penelitian ini merupakan eksperimental laboratorium dengan desain posttest control group design. Sampel penelitian yang digunakan yaitu 27 plat resin akrilik heat cured berukuran 10x10x2 mm. Sampel dibagi menjadi 3 kelompok, masing-masing kelompok terdiri dari 9 plat resin akrilik heat cured, yang direndam dalam rebusan daun sirih 50\%, 70\% dan aquadest sebagai kelompok kontrol selama 30 menit Perhitungan Candida albicans dengan colony counter.Data yang diperoleh dianalisis menggunakan Kruskal-Wallis. Hasil: berdasarkan hasil analisis diperoleh nilai $\mathrm{p}=0.000(\mathrm{p}<0.05)$, hal ini menunjukkan bahwa terdapat perbedaan bermakna antara masing-masing kelompok sampel. Kesimpulan: rebusan daun sirih $50 \%$ dan $70 \%$ dapat menurunkan jumlah Candida albicans pada plat resin akrilik heat cured. Rebusan daun sirih $70 \%$ lebih menurunkan jumlah Candida albicans pada plat resin akrilik heat cured dibanding rebusan daun sirih 50\%.
\end{abstract}

Kata kunci: daun sirih, akrilik, Candida albicans

\begin{abstract}
Introduction: denture that was made from acrylic resin often can be a place for the growth of Candida albicans colonies, and if the denture is not cleaned properly, it can cause Candidiasis. To eliminate the growth of the amount of Candida albicans, Piper betle $L$ can be used as the alternative way to clean the denture. Piper betle L. known as antifungal and desinfectan. Objectives: The aim of this study is to determine the effect of boiled Piper betle L 50\% and $70 \%$ to the growth of Candida albicans. Methods: this research was an experimental laboratory with posttest control group design. This research sample used 27 heat cured acrylic resin plates with the size of plates $10 \times 10 \times 2 \mathrm{~mm}$. The sample were divided into 3 groups of immersion; concentration 50\% of boiled Piper betle L., $70 \%$ of boiled Piper betle L., and sterile distilled water as the control group. Each group consisted of 9 heat cured acrylic resin plates, which were immersed for 30 minutes. Then, counted the amount of Candida albicans colonies by colony counter.Data was analyzed by using Kruskal-Wallis. Results: based on the results of analyzed obtained $p$ value $=0.000(p<0.05)$, there is a significant difference between each group. Conclusion: from results of this research can be concluded that $50 \%$ and $70 \%$ of boiled Piper betle L. effect in decreasing the amount of Candida albicans on heat cured acrylic resin plates. $70 \%$ of boiled Piper betle L. further reducing the amount of Candida albicans on heat cured acrylic resin plate than $50 \%$ of boiled Piper betle $L$.
\end{abstract}

Keywords: betel leaves, acrylic, Candida albicans

\section{PENDAHULUAN}

$\mathrm{R}$ esin akrilik yang sering digunakan sebagai bahan basis gigi tiruan adalah resin akrilik heat cured karena tidak toksik dan tidak mengiritasi, tidak larut dalam cairan mulut, murah, mudah dimanipulasi, dan apabila mengalami fraktur dapat dengan mudah diperbaiki. ${ }^{1}$ Permukaan akrilik yang menghadap mukosa, biasanya memiliki pit dan porositas mikro yang dapat menjadi tempat akumulasi organisme mikro. ${ }^{2}$ Pemakaian gigi tiruan 
resin akrilik yang terus menerus dan tidak bersih dapat menyebabkan penumpukan plak dan meningkatnya jumlah pertumbuhan Candida albicans. Telah terbukti bahwa pembersih gigi tiruan berperan efektif dalam menurunkan jumlah Candida albicans. ${ }^{3}$ Atas dasar tersebut, pembersihan gigi tiruan harus diperhatikan. ${ }^{2}$ Obat tradisional yang berasal dari tumbuh-tumbuhan dan tanam-tanaman di Indonesia dapat dipakai sebagai bahan pembersih gigi tiruan. ${ }^{4}$ Jenis tanaman yang termasuk dalam kelompok tanaman obat salah satunya yaitu sirih (Piper betle L.). Daun sirih mengandung 4,2\% minyak atsiri. ${ }^{5}$ Kandungan fenol (karvakol) dan fenil propan (eugenol dan kavikol) di dalam minyak atsiri daun sirih hijau berfungsi sebagai antiseptik (bakterisida dan fungisida) yang sangat kuat. ${ }^{8}$ Sifat bakterisida dan fungisida daun sirih ini sangat bermanfaat jika digunakan untuk mengobati infeksi mikroorganisme patogen pada tubuh manusia seperti menghambat pertumbuhan Candida albicans. ${ }^{5,3}$

Berdasarkan uraian terdapat rumusan masalah yaitu apakah rebusan daun sirih 50\% dan 70\% berpengaruh terhadap penurunan jumlah Candida albicans pada plat resin akrilik heat cured. Tujuan penelitian ini adalah untuk membuktikan adanya pengaruh rebusan daun sirih $50 \%$ dan $70 \%$ terhadap penurunan jumlah Candida albicans pada plat resin akrilik heat cured.

\section{METODE}

Penelitian ini merupakan penelitian eksperimental laboratorium yang dilakukan di Laboratorium Mikrobiologi dan Fermentasi, Balai Pengkajian Bioteknologi, BPPT pada bulan Agustus 2017. Sampel yang digunakan adalah plat resin akrilik heat cured (merek Vertex BasiQ 20, Netherland) berukuran 10x10x2mm. Sampel penelitian ini berjumlah 27 plat akrilik yang dibagi menjadi 2 kelompok perlakuan dan 1 kelompok kontrol, diantaranya yaitu:

Kelompok I : Air rebusan daun sirih dengan konsentrasi 50\%

Kelompok II : Air rebusan daun sirih dengan konsentrasi $70 \%$

Kelompok III : Aquadest steril

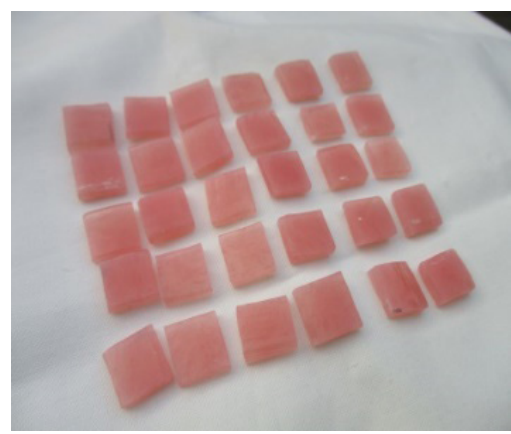

Gambar 1. Plat resin akrilik heat cured ukuran $10 \times 10 \times 2 \mathrm{~mm}$
Penelitian ini telah lolos kaji etik dengan No.0072013/loloskaji etik/FKGUPDM(B)/XII/2016

Tahapan penelitian dimulai dengan merendam plat resin akrilik heat cured yang sudah dilakukan finishing dan polishing, dengan merendamnya ke dalam aquades steril selama $48 \mathrm{jam}$. Plat resin akrilik disterilkan dengan autoclave $121^{\circ} \mathrm{C}$ selama 15 menit. Sediaan Candida albicans yang digunakan pada penelitian ini adalah American Type Culture Cell (ATCC) 10231 yang diperoleh dari Laboratorium Mikrobiologi BPPT. Koloni Candida albicans dimasukkan ke dalam tabung reaksi dengan cara goresan pada agar miring sebanyak 1 ose, kemudian Inkubasi $36 \pm 1^{\circ} \mathrm{C}$ selama 24 jam sehingga diperoleh suspensi Candida albicans. Lalu menambahkan $2 \mathrm{ml}$ air kedalam tabung reaksi yang berisi agar miring, kemudian $1 \mathrm{ml}$ dari larutan tersebut dimasukkan ke dalam larutan yang berisi $25 \mathrm{ml}$ Sabouraud Dextrose Broth (SDB).

Setelah plat resin akrilik heat cured disterilkan, diambil dengan pinset steril untuk direndam dalam saliva buatan selama 1 jam untuk memudahkan perlekatan Candida albicans dengan plat resin akrilik. Plat resin akrilik diinkubasi selama 24 jam padasuhu $37^{\circ} \mathrm{C}$ di dalam suspense Candida albicans. Kemudian 9 plat resin akrilik direndam dalam $10 \mathrm{ml}$ larutan rebusan daun sirih $50 \%, 9$ plat resin akrilik direndam dalam $10 \mathrm{ml}$ larutan rebusan daun sirih $70 \%$, dan 9 plat resin akrilik direndam dalam aquadest steril sebagai kelompok kontrol, masing-masing kelompok direndam selama 30 menit.

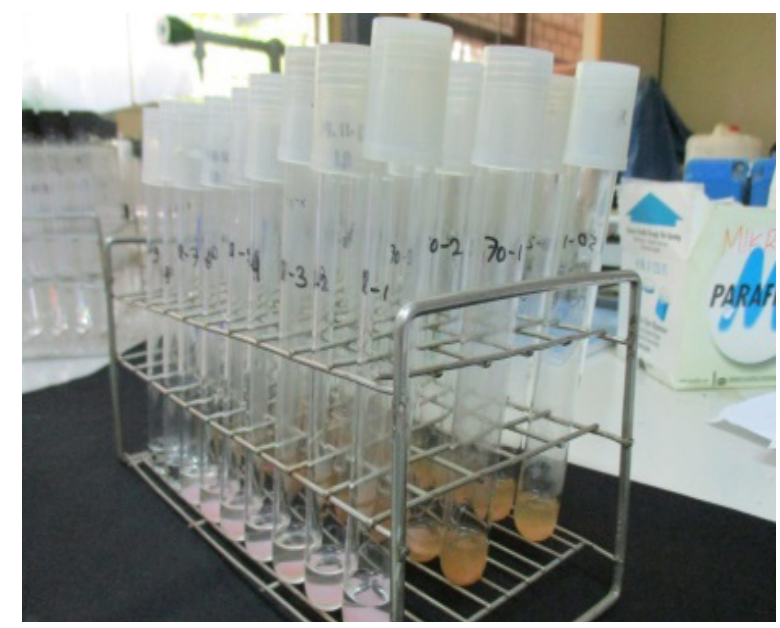

Gambar 2. Plat resin akrilik direndam dalam larutan rebusan daun sirih 50\%, 70\% dan aquadest

Plat resin akrilik kemudian dibilas dengan aquadest steril sebanyak dua kali, lalu dimasukkan ke dalam $10 \mathrm{ml}$ larutan $\mathrm{NaCl} 0,85 \%$ dan divibrasi dengan vortex selama 15 detik. Masing-masing tabung dilakukan pengenceran seri dengan metode pour plate sampai mencapai suspense $10^{-3} \mathrm{CFU} / \mathrm{ml}$. Hasil pengenceran seri Candida albicans ditanam dalam media Sabouraud Dextrose Agar (SDA) $\pm 15-18 \mathrm{ml} /$ 
cawan, lalu diinkubasi pada suhu $36 \pm 1^{\circ} \mathrm{C}$ selama 24 48 jam. Selanjutnya, dilakukan perhitungan jumlah sel menggunakan colony counter.

\section{HASIL PENELITIAN}

Hasil penelitian menunjukkan bahwa rebusan daun sirih $50 \%$ dan $70 \%$ dapat menurunkan jumlah Candida albicans pada plat resin akrilik heat cured.

Tabel 1. Hasil perhitungan jumlah koloni Candida albicans $(C F U / m L)$ pada plat resin akrilik setelah perendaman

\begin{tabular}{lccc}
\hline & n & $\begin{array}{c}\text { Median } \\
\text { (minimum- } \\
\text { maksimum) }\end{array}$ & p \\
\hline $\begin{array}{l}\text { Larutan Rebusan } \\
\text { Daun Sirih 50\% }\end{array}$ & 9 & $100(100-650)$ & 0,000 \\
$\begin{array}{l}\text { Larutan Rebusan } \\
\text { Daun Sirih 70\% }\end{array}$ & 9 & $100(100-100)$ & \\
Larutan Aquadest & 9 & $1800(1100-9100)$ & \\
\hline
\end{tabular}

Tabel 1 menunjukkan bahwa rerata jumlah jumlah koloni Candida albicans pada alat colony counter pada kelompok larutan rebusan daun sirih $50 \%$ adalah 183,33, dan pada kelompok larutan rebusan daun sirih 70\% adalah 100,00 dan pada larutan aquadest adalah 3766,67 .

Tabel 2. Hasil uji Kruskal-Wallis

\begin{tabular}{cccc}
\hline & n & Mean & SD \\
\hline $\begin{array}{c}\text { Rebusan Daun } \\
\text { Sirih 50\% }\end{array}$ & 9 & 183,33 & 182,003 \\
$\begin{array}{c}\text { Rebusan Daun } \\
\text { Sirih 70\% }\end{array}$ & 9 & 100,00 & 0,000 \\
Aquadest & 9 & 3766,67 & $3,284,052$ \\
\hline
\end{tabular}

Uji Kruskal-Wallis, Uji post-hoc Mann-Whitney: rebusan daun sirih $50 \%$ vs rebusan daun sirih $70 \% \mathrm{p}=0,067$; rebusan daun sirih $50 \%$ vs aquadest $\mathrm{p}<0,05$; rebusan daun sirih $70 \%$ vs aquadest $\mathrm{p}<0,05 ; \mathrm{CI}=95 \%$

Tabel 2 menunjukkan hasil uji statistic dengan uji Kruskal-Wallis diperoleh nilai $\mathrm{p}=0,000(\mathrm{p}<0,05)$. Hal ini berarti terdapat perbedaan bermakna antara perendaman dengan rebusan daunsirih 50\%, rebusandaunsirih 70\% dan aquadest. Berdasarkan hasil tersebut, terdapat penurunan jumlah Candida albicans pada plat resin akrilik heat cured yang artinya hipotesis diterima.

\section{PEMBAHASAN}

Hasil penelitian menunjukkan bahwa perendaman plat resin akrilik heat cured dalam rebusan daun sirih $50 \%$ dan $70 \%$ secara signifikan dapat menurunkan jumlah koloni Candida albicans (Tabel 2). Hal ini dapat terjadi karena daun sirih mengandung minyak atsiri yang bersifat antiseptik, antioksidan, mempunyai aktivitas terhadap beberapa bakteri gram positif maupun bakteri gram negatif serta mempunyai sifat anti jamur. ${ }^{1}$ Cairan hasil rebusan daun sirih akan menghasilkan ekstrak daun sirih berwarna kuning muda kehijauan dan bersifat asam dengan $\mathrm{pH} \pm 4$. Semakin banyak daun sirih yang direbus, maka tingkat keasaman cairan rebusannya akan bertambah. ${ }^{2}$ Pada penelitian sebelumnya oleh Galuh Martin (2010), minyak atsiri daun sirih hijau dengan konsentrasi $25 \%$ menghasilkan zona hambat yang besar terhadap pertumbuhan Candida albicans, hal ini menunjukkan bahwa daun sirih memiliki efek antifungi terhadap Candida albicans secara in vitro. ${ }^{3}$

Penelitian ini menggunakan plat resin akrilik Vertex BasiQ 20 tipe heat cured karena masih digunakan sebagai basis gigi tiruan dibidang kedokteran gigi saat ini terutama prostodonsia. Resin akrilik saat ini menjadi bahan pilihan karena resin akrilik (poly methyl methacrylate) memiliki kualitas estetik yang baik, mudah untuk diproses, murah, tidakmemilikibaudan rasa sertamudah dibersihkan. ${ }^{4}$ Beberapa kerugian yang dimiliki oleh resin akrilik ialah tidak tahan terhadap abrasi, menyerap cairan, mudah patah, dan porositas akibat adanya monomer sisa yang menyebabkan topografi permukaan resin akrilik menjadi tidak rata dan kasar sehingga dapat menjadi tempat ideal untuk melekatnya sisa makanan serta pertumbuhan mikroorganisme di dalam rongga mulut, salah satunya Candida albicans. ${ }^{5,6}$

Nilai rerata yang tinggi pada jumlah koloni Candida albicans dari kelompok kontrol oleh karena aquadest steril merupakan tempat yang baik bagi pertumbuhan koloni Candida albicans. Hal ini disebabkan oleh suasana anaerob pada basis gigi tiruan, sehingga mikroorganisme seperti Candida akan tumbuh lebih banyak. Metode hitungan cawan yang digunakan yaitu metode pour plate (Gambar 3), dengan menghitung jumlah koloni Candida albicans yang telah dibiakkan tanpa bantuan mikroskop. Hasil perhitungan tidak selalu menunjukkan jumlah sel yang sebenarnya, karena sel yang berdekatan kemungkinan membentuk koloni. (Gambar 4)

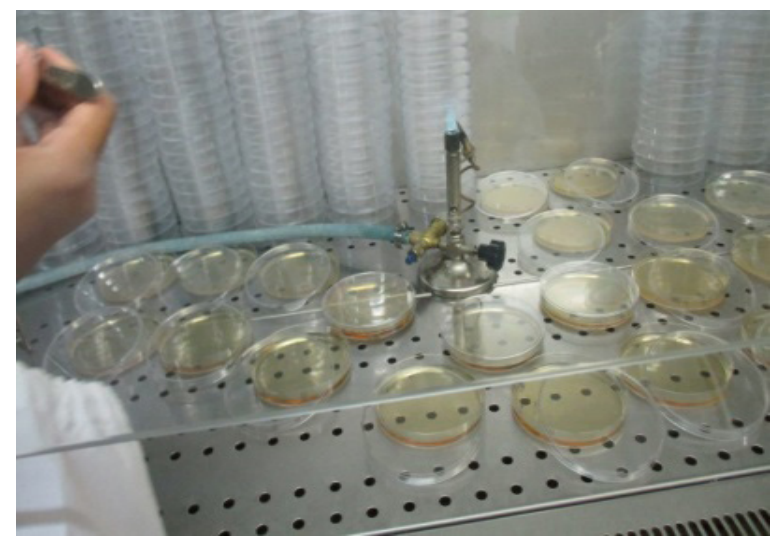

Gambar 3. Proses pengenceran seri dan metode pour plate 


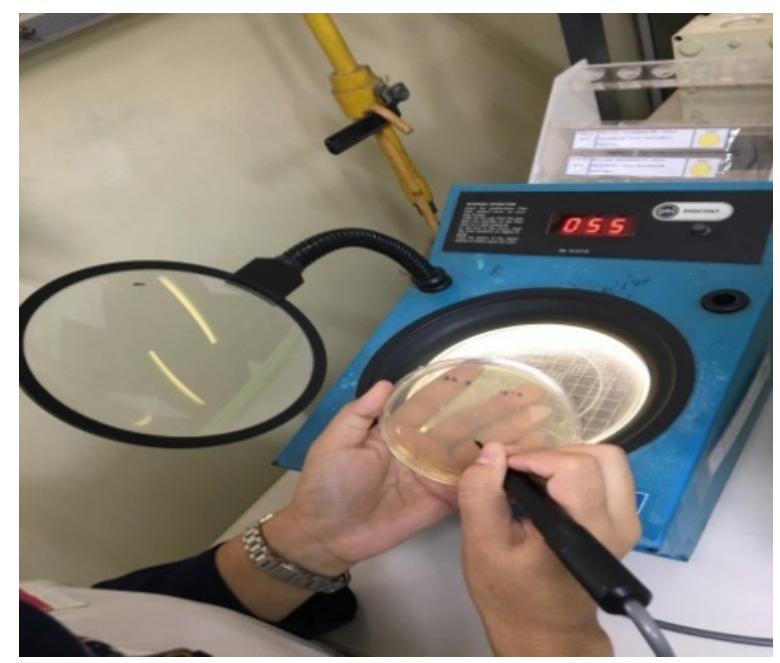

Gambar 4. Menghitung jumlah koloni Candida albicans menggunakan colony counter

Penelitian ini sesuai dengan penelitian yang dilakukan oleh Indah Rahayu dkk (2014) yang menggunakan rebusan daun sirih $25 \%$ dan $50 \%$, dengan hasil terdapat kecenderungan semakin tinggi konsentrasi rebusan daun sirih maka semakin rendah pertumbuhan Candida albicans pada plat resin akrilik setelah dilakukan perendaman. ${ }^{7}$ Oleh karena itu, hasil dari penelitian ini diharapkan dapat bermanfaat dalam bidang kedokteran gigi, sehingga masyarakat dapat menyadari betapa daun sirih memiliki banyak keunggulan dan dapat dimanfaatkan untuk membersihkan gigi tiruan secara rutin. Daun sirih selain berasal dari tanaman tradisional, murah, dan mudah ditemukan, pengelolaannya mudah serta pemanfaatan daun sirih dapat menghindari terjadinya denture stomatitis.

\section{KESIMPULAN}

Berdasarkan hasil penelitian yang telah dilakukan, dapat disimpulkan bahwa rebusan daun sirih memiliki zat aktif yang berkhasiat sebagai anti jamur, desinfektan serta memiliki sifat bakteriostatik dan bakteriosid. Hal tersebut terbukti dari adanya penurunan jumlah Candida albicans pada plat resin akrilik heat cured setelah direndam dalam rebusan daun sirih $50 \%$ dan $70 \%$. Pada tahap selanjutnya, diharapkan adanya penelitian lebih lanjut mengenai pengaruh rebusan daun sirih terhadap mikroba jenis lain dalam rongga mulut serta metode pembersihan gigi tiruan selain perendaman.

\section{DAFTAR PUSTAKA}

1. Munadziroh E, Muslita I. Bahan Pembersih Gigi Tiruan untuk Mencegah Pertumbuhan Candida albicans. Surabaya: Majalah Kedokteran Gigi FKG Unair. 2001;9: 84-90.

2. Antolis M. Pengaruh Lama Perendaman dalam Rebusan Daun Sirih(Piper betle) terhadap Kekuatan Transversa Resin Akrilik self cured.[Skripsi]. Makassar: Fakultas Kedokteran Gigi Universitas Hasanuddin. 2014.

3. Maytasari, GM. Perbedaan Efek Antifungi Minyak Atsiri Daun Sirih Hijau, Minyak Atsiri Daun Sirih Merah, dan Resik-V Sabun Sirih terhadap Pertumbuhan Candida albicans secara in vitro. [Skripsi]. Surakarta: FK Universitas Sebelas Maret. 2010.

4. Noort RV. Introduction to Dental Materials. $3^{\text {rded. }}$ Edinburgh: Mosby. 2007:216-17.

5. Tunggal EG, Dharmautama M, Jubhari EH. Perubahan Warna Basis Akrilik Penggunaan Pasta Pembersih Gigi Tiruan Rosella. Majalah Kedokteran Gigi (Dentofasial) 2015:14:1:25-7.

6. Adifaizal H. Perbandingan Ffektivitas Cairan Desinfektan Alat Ortodontik Lepasan Chlorhexidine dengan Cairan Ekstrak Daun Sirih terhadap Jumlah Candida albicans. [Skripsi]. Yogyakarta: Fakultas Kedokteran Gigi Universitas Gadjah Mada. 2013. (Diakses 24 Oktober 2016). Tersedia di: http://etd.repository.ugm.ac.id/index.php?mod=penelitian detail\&sub=PenelitianDetail\&act=view\&typ=html\&buku_ id $=65016$

7. Rahayu I, Fadriyanti O, Edrizal. Efektivitas Pembersih Gigi Tiruan dengan Rebusan Daun Sirih 25\% dan 50\% terhadap Pertumbuhan Candida albicans pada Lempeng Resin Akrilik Polimerisasi Panas. Majalah Kedokteran Gigi (Jurnal B-Dent) 2014:1:142-9. 